\title{
Detection of Begomoviruses in Clarified Plant Extracts: A Comparison of Standard, Direct-Binding, and Immunocapture Polymerase Chain Reaction Techniques
}

\author{
S. N. Rampersad and P. Umaharan
}

Department of Life Sciences, The University of the West Indies, St. Augustine, The Republic of Trinidad and Tobago. Accepted for publication 14 April 2003.

\begin{abstract}
Rampersad, S. N., and Umaharan, P. 2003. Detection of begomoviruses in clarified plant extracts: A comparison of standard, direct-binding, and immunocapture polymerase chain reaction techniques. Phytopathology 93:1153-1157.

Three polymerase chain reaction (PCR) techniques - standard PCR (Std-PCR), direct-binding PCR (DB-PCR), and immunocapture PCR (ICPCR) - using degenerate primers were optimized and evaluated for the detection of begomoviruses. Tomato leaf samples were ground in three different extraction buffers and subjected to Std-PCR. The effect of the buffers on the detection limits of amplification of the virus (detection of the initial and end points of dilution) was determined. With the optimal extraction buffer determined by the first experiment, the antibody concentration and incubation conditions for IC-PCR were evaluated to determine the requirements for maximum capture of antigens during the capture phase of the technique. The incubation conditions of DB-PCR
\end{abstract}

ABSTRACT were also investigated to determine the most favorable conditions for adsorption of the viral template. The reproducibility of all assays was evaluated. With the results of the optimization experiments, the applicability of the three techniques to different plant species was assessed. Extracts of plant species belonging to three families were subjected to the optimized Std-, DB-, and IC-PCR protocols. Std- and IC-PCR both achieved reproducible detection of begomoviruses, but the detection limits and amplified band intensity for all plant species tested were superior for the latter. DB-PCR was an unreliable method of detection, because of poor reproducibility and low intensity of amplified bands. These results indicate that the optimized IC-PCR detection system using degenerate primers is the most effective for the detection of begomoviruses in clarified plant extracts.

Additional keywords: antigen-capture polymerase chain reaction, diagnosis, tube-capture polymerase chain reaction.
With the recent epidemic status of whitefly-transmitted geminivirus diseases in the Western Hemisphere, the family Geminiviridae has become one of the major groups of phytopathogens in many vegetable agroecosystems throughout the region $(1,19)$. Whitefly-transmitted geminiviruses belong to the genus Begomovirus, members of which possess a bipartite genome and are transmitted by an insect vector, the whitefly Bemisia tabaci, to many dicotyledonous host plants. During the past decade numerous begomoviruses have been reported in the region $(2,6,9,16,19-21,23$, 24,27,30). In Trinidad and Tobago, Potato yellow mosaic virus Trinidad isolate (PYMV-TT) has been identified as the causal agent of viral epidemics observed in tomato since the late 1980s (30). PYMV-TT infection of tomato is manifested by interveinal chlorosis; yellow mottling or mosaic of leaves; leaf malformations, including severe epinasty and crinkling; leaf size reduction; and, in severe infection, stunting of the whole plant.

Historically, begomoviruses have been characterized by symptomatology and host range tests. A reliance on symptom development as the sole indicator of infection may impede diagnosis, as symptoms are affected by several variables, such as the virus strain, the growth stage of the plant at the time of infection, the plant cultivar, and environmental conditions $(1,19)$. However, fast, accurate, highly sensitive, and reproducible diagnostic assays for detecting begomoviruses have been developed. Among several diagnostic tools available, the polymerase chain reaction (PCR) using degenerate primers has been the most useful for the detection of geminiviruses $(8,25,28,33)$. PCR is especially useful for detect-

Corresponding author: P. Umaharan; E-mail address: pumaharan@lifsc.uwi.tt

Publication no. P-2003-0616-03R

(C) 2003 The American Phytopathological Society ing begomoviruses, because of its sensitivity to the viral template in low titers. In addition, taxonomically informative domains may be amplified by PCR and used in identification and phylogenetic studies $(11,18,25,27,30)$.

Conventional PCR protocols require the preparation of total nucleic acids from infected plants for successful amplification of viral DNA templates. Methods of DNA isolation and purification are not only laborious but also may not be universally applicable to different plant species, especially those with high levels of polysaccharides or phenolics $(7,33)$. As a consequence, template preparation can be a limitation on PCR detection of begomoviruses. Direct-binding PCR (DB-PCR), based on the adsorption of viral particles to the surface of a polypropylene microcentrifuge tube, has been assessed for the detection of viruses $(26,33)$. Similarly, immunocapture PCR (IC-PCR), or antigen-capture PCR, has been used to detect plant viruses, such as Plum pox virus, Apple chlorotic leaf spot virus, Prunus necrotic ringspot virus, and Banana streak virus $(3-5,10,14,22,26,31,32)$.

The objectives of this study were to optimize and evaluate three PCR techniques using degenerate primers - standard PCR (StdPCR), DB-PCR, and IC-PCR - for efficient detection of begomoviruses in clarified leaf extracts of different plant species.

\section{MATERIALS AND METHODS}

Collection of plant material. The plants selected for study were Lycopersicon esculentum Mill. (Solanaceae); Sida acuta J. Burm. and S. rhombifolia L. (Malvaceae); and Calopogonium mucunoides Desv. and Rhynchosia minima (L.) DC. (Fabaceae), each a known host of geminiviruses. Young, newly emerged leaves from symptomatic plants of each species were placed in labeled bags and transported to the laboratory on ice. L. esculentum was col- 
lected from Aranguez and Pasea, large commercial tomato-growing areas in north Trinidad. S. acuta and S. rhombifolia were collected as wayside weeds from Toco Main Road, in northeastern Trinidad. $C$. mucunoides and R. minima were collected as wayside weeds at the University of the West Indies Field Station in Mt. Hope, in north Trinidad. Healthy leaf samples of L. esculentum (used as negative controls) were collected from virus-free greenhousemaintained plants at the University of the West Indies. Uninfected leaves of Sida spp. were collected from Santa Cruz, in northwestern Trinidad, and uninfected leaves of C. mucunoides and R. minima were collected at Mt. Hope.

Preparation of clarified extracts. One gram of fresh foliar tissue was weighed, washed briefly in distilled water, and cut into strips with a sterile scalpel blade. Samples were ground separately in a sterile mortar and pestle in each of the three buffers (A, B, and $\mathrm{C}$ ) at a ratio of 1:5 (wt/vol) at room temperature. The extracts were subsequently filtered through a rayon polyester filter (Miracloth, Calbiochem-Novabiochem, La Jolla, CA) and serially diluted $\left(2^{0}\right.$ to $\left.2^{-10}\right)$ in the same buffers used for grinding. Buffer A contained $10 \mathrm{mM}$ Tris- $\mathrm{HCl}(\mathrm{pH} \mathrm{8.0)}$ and $1 \mathrm{mM}$ EDTA (pH 8.0); buffer B, $500 \mathrm{mM}$ Tris- $\mathrm{HCl}$ (pH 8.0), $2 \%$ polyvinylpyrrolidone (PVP-40), 1\% polyethylene glycol (PEG-8000), $140 \mathrm{mM} \mathrm{NaCl}$, and $0.05 \%$ Tween $20(\mathrm{pH} \mathrm{8.3)}$; and buffer C, $20 \mathrm{mM}$ Tris- $\mathrm{HCl}(\mathrm{pH}$ 8.0), $138 \mathrm{mM} \mathrm{NaCl}, 1 \mathrm{mM}$ PVP, $0.05 \%$ Tween $20,3 \mathrm{mM} \mathrm{KCl}$, and $3 \mathrm{mM} \mathrm{NaN}_{3}$ per liter ( $\mathrm{pH}$ 7.4).

Oligonucleotide primers and PCR amplification. For a single reaction of $50 \mu \mathrm{l}$, the PCR included $20 \mathrm{mM}$ Tris- $\mathrm{HCl}(\mathrm{pH} \mathrm{8.4)}$, $50 \mathrm{mM} \mathrm{KCl}, 1.5 \mathrm{mM} \mathrm{MgCl} 2,0.2 \mathrm{mM}$ deoxynucleoside triphosphate (dNTP), 1\% Tween 20, 2.5 U Taq DNA Polymerase (Gibco BRL, Gaithersburg, MD), and 50 pmol of each primer. The reaction mix was overlaid with PCR-grade sterile mineral oil and subjected to amplification in a Touchgene Gradient thermal cycler (Techne, Cambridge, U.K.) programmed for $5 \mathrm{~min}$ at $94^{\circ} \mathrm{C}$, followed by 40 cycles of $1 \mathrm{~min}$ at $94^{\circ} \mathrm{C}, 1 \mathrm{~min}$ at $55^{\circ} \mathrm{C}$, and $2 \mathrm{~min}$ at $72^{\circ} \mathrm{C}$, with a final extension of $5 \mathrm{~min}$ at $72^{\circ} \mathrm{C}(30)$.

The degenerate primers MP16 (5'-CCTCTAGATAATATTACCKRWKGRCC-3') and MP82 (5'-CGGAATTCYTGNACYTTRCANGGNCCYTCRCA-3') were designed to anneal to the invariable sequence of a nonanucleotide (TAATATTAC) located in the conserved stem-loop region and the eight invariable codons that are present in the $5^{\prime}$ terminal domain of the begomovirus capsid protein gene, respectively. These primers were predicted to direct the amplification of a fragment of PYMV DNA-A consisting of approximately $400 \mathrm{bp}$ (nucleotides 167 to 506) (30).

Optimization of Std-PCR. The effects of several additives to the general PCR mix were evaluated in an attempt to maximize amplification. Three additives-glycerol (20\%), Tween 20 (1\%), and dimethyl sulfoxide (5\%)-and varying concentrations of $\mathrm{MgCl}_{2}(2.5,2.0,1.5$, and $1.0 \mathrm{mM})$ were tested. The combination of Tween $20(1 \%)$ and $1.5 \mathrm{mM} \mathrm{MgCl}$ in the PCR mix resulted in amplification of geminivirus fragments from highly diluted tomato extracts and was used in all subsequent PCR assays. Serial dilutions $\left(2^{0}\right.$ to $\left.2^{-10}\right)$ were prepared from extracts of PYMV-TTinfected tomato in each buffer, and $1 \mu \mathrm{l}$ of each dilution was dispensed in $50 \mu \mathrm{l}$ of PCR mix for amplification. The extracts were subjected to Std-PCR in at least two replications. The differences in detection limits (detection of the initial and end points of dilution) and amplified band intensity were recorded. Negative controls consisted of healthy tomato extracts diluted to $2^{-5}$ in buffer $\mathrm{C}$.

Optimization of DB-PCR. With the optimum buffer identified in the previous experiment, the requirements for maximum adsorption of the viral template to microcentrifuge tube walls were determined by varying the incubation conditions in the adsorption phase of this method. Serial dilutions $\left(2^{0}\right.$ to $\left.2^{-10}\right)$ of extracts of infected tomato tissue were prepared in buffer $\mathrm{C}$, and $50-\mu \mathrm{l}$ aliquots of each dilution were dispensed in sterile $0.5-\mathrm{ml}$ polypropylene microcentrifuge tubes, which were either incubated at $37^{\circ} \mathrm{C}$ for $2 \mathrm{~h}$ and then washed twice with enzyme-linked immunosorbent assay
(ELISA) wash buffer (Bioreba, Reinach, Switzerland), containing $138 \mathrm{mM} \mathrm{NaCl}, 1.5 \mathrm{mM} \mathrm{KH} \mathrm{PO}_{4}, 8 \mathrm{mM} \mathrm{Na} \mathrm{HPO}_{4}, 3 \mathrm{mM} \mathrm{KCl}$, $0.05 \%$ Tween 20 , and $3 \mathrm{mM} \mathrm{NaN}_{3}$ per liter ( $\mathrm{pH} 7.4$ ), or incubated at $4{ }^{\circ} \mathrm{C}$ for $16 \mathrm{~h}$ and then washed three times. The tubes were then air-dried for approximately $15 \mathrm{~min}$ and subjected to PCR amplification to determine detection limits (initial and end points of dilution). Two replications were tested, to assess reproducibility. Negative controls consisted of extracts of healthy tomato leaves diluted to $2^{-5}$ in buffer $\mathrm{C}$.

Optimization of IC-PCR. The effect of antibody concentration $(1: 500$ and $1: 1,000)$ and incubation conditions $\left(37^{\circ} \mathrm{C}\right.$ for $2 \mathrm{~h}$ versus $4^{\circ} \mathrm{C}$ for $16 \mathrm{~h}$ ) in the precoating and capture phases were evaluated in factorial combinations $(2 \times 2)$ to determine the detection limits of PCR reactions using serial dilutions of tomato extracts in buffer C. The antibodies (Bioreba) used in the coating step are polyclonal, produced in rabbits and raised against a recombinant coat protein of cabbage leaf curl virus (CaLCV). In ELISA, the antibodies reacted with $\mathrm{CaLCV}$, Bean golden mosaic virus (BGMV), and Tomato mottle virus (ToMoV). In Western blots, CaLCV, BGMV, ToMoV, Tomato yellow leaf curl virus-Israel, and Sida golden mosaic virus Florida isolate were recognized. For this optimization study, the antibodies were diluted to $1: 500$ and $1: 1000$ in precoating carbonate buffer (Bioreba), containing $15 \mathrm{mM}$ $\mathrm{Na}_{2} \mathrm{CO}_{3}, 35 \mathrm{mM} \mathrm{NaHCO}$, and $3 \mathrm{mM} \mathrm{NaN}_{3}$ (pH 9.6). Aliquots $(50 \mu \mathrm{l})$ of the diluted antibody were dispensed in sterile $0.5-\mathrm{ml}$ microcentrifuge tubes. The tubes were incubated at $37^{\circ} \mathrm{C}$ for $2 \mathrm{~h}$ and then washed twice with ELISA wash buffer or incubated at $4^{\circ} \mathrm{C}$ for $16 \mathrm{~h}$ and then washed three times. Infected tomato leaf tissue was ground in extraction buffer $\mathrm{C}$ in a ratio of $1: 5$ (wt/vol) and filtered through Miracloth, and serial dilutions of $2^{0}$ to $2^{-20}$ were prepared. Aliquots $(50 \mu \mathrm{l})$ of each dilution were dispensed in the antibody-coated tubes. The tubes were incubated for another $2 \mathrm{~h}$ at $37^{\circ} \mathrm{C}$ and then washed two times or incubated for $16 \mathrm{~h}$ at $4^{\circ} \mathrm{C}$ and then washed three times. The tubes were then dried by inversion for $15 \mathrm{~min}$. The PCR mix $(50 \mu \mathrm{l})$ was then added to each tube, and PCR amplification was performed. Two replications were carried out, to assess reproducibility. Negative controls consisted of healthy tomato extracts prepared and diluted to $2^{-5}$ in buffer C.

Comparison of Std-, DB-, and IC-PCR in assaying different plant species. With the optimized PCR protocols developed, a comparative evaluation was carried out with $L$. esculentum, $R$. minima, C. mucunoides, and Sida spp. infected with geminiviruses. Infected leaves of each plant species were ground in extraction buffer $\mathrm{C}$ ( $\mathrm{pH} 7.4)$, and serial dilutions $\left(2^{0}\right.$ to $\left.2^{-20}\right)$ were prepared. The detection limits for each species were determined by subjecting the diluted extracts to the three PCR techniques. Negative controls consisted of extracts of healthy leaves of each species, ground and diluted to $2^{-5}$ in buffer $\mathrm{C}$ (this dilution was tested for the presence of nonspecific amplified band formation).

Analysis of PCR products. The PCR amplification products were analyzed in $1.4 \%$ agarose gels stained with ethidium bromide and photo-documented with the Imagestore 7500 Gel Documentation System (UVP, Cambridge, U.K.).

\section{RESULTS}

Optimization of Std-, DB-, and IC-PCR. Among the three extraction buffers tested with Std-PCR, amplification from the greatest number of dilutions $\left(2^{0}\right.$ to $\left.2^{-9}\right)$ occurred in buffer $\mathrm{C}$, followed by buffer $\mathrm{B}\left(2^{-1}\right.$ to $\left.2^{-5}\right)$ and buffer $\mathrm{A}\left(2^{-2}\right.$ to $\left.2^{-5}\right)$. As a result, only buffer $\mathrm{C}$ was used with the other two methods.

In DB-PCR, there was a small improvement in detection from the lower dilution end point of tomato extracts $\left(2^{-8}\right.$ to $\left.2^{-10}\right)$ when the incubation conditions were changed from $37^{\circ} \mathrm{C}$ for $2 \mathrm{~h}$ with two washes to $4^{\circ} \mathrm{C}$ for $16 \mathrm{~h}$ with three washes (the initial detection point remained unchanged, at $2^{0}$ ). There was also some increase in band intensity over the first three dilutions under the latter incubation 
conditions. However, the reproducibility was poor with respect to both detection limits and intensity of the amplified band, even for comparisons with the same dilutions (Table 1). Because of these results, DB-PCR was not used for the other test plants, except for Sida spp. Extracts of Sida spp. are very mucilaginous, and the high level of polysaccharides may affect the amplification reaction in Std-PCR (7). DB-PCR is intended to isolate the viral template from the rest of the extract through adsorption of viral DNA to the microcentrifuge tube wall, thereby improving amplification. However, results were again inconsistent for Sida spp., both for amplified band intensity and detection of the initial and end points of dilution.

Optimal conditions for IC-PCR assay of all plant species were an antibody concentration of 1:500 and overnight incubation (16 h at $4^{\circ} \mathrm{C}$ ) followed by three washes with ELISA wash buffer. After incubation at $4{ }^{\circ} \mathrm{C}$ for $16 \mathrm{~h}$, the antibody dilution of $1: 500$ allowed detection at a considerably lower dilution end point $\left(2^{-13}\right)$ and extended band intensity, compared to the 1:1,000 antibody dilution (lower dilution end point of $2^{-7}$ ), while the initial detection point was $2^{0}$ for both protocols. Preliminary studies using clarified leaf extracts of Sida spp. showed that an antibody dilution of $1: 250$ did not provide additional improvement in the detection limit (with dilutions of $2^{-10}$ to $2^{-20}$ ), and hence this antibody dilution was not tested with extracts of other plant species. Incubation for $16 \mathrm{~h}$ at $4^{\circ} \mathrm{C}$ improved both the detection limit and the intensity of the amplified band with the 1:500 antibody dilution, indicating a more efficient capture of antigens by antibodies, compared with $2 \mathrm{~h}$ of incubation at $37^{\circ} \mathrm{C}$. The bands obtained after the $16-\mathrm{h}$ incubation were very distinct and of high intensity. Figure 1 shows the relative amplified band intensities obtained when the same tomato extract dilutions were subjected to PCR amplification with all three assays. Amplification products were not obtained for the negative controls.

Comparison of Std-, DB-, and IC-PCR in assaying different plant species. Table 2 lists the detection limits for Sida spp., $R$. minima, C. mucunoides, and L. esculentum when serial dilutions of each were subjected to the three optimized PCR-based assays. The lowest dilution in which detection was achieved by Std-PCR was for L. esculentum $\left(2^{0}\right.$, undiluted extract), and the greatest dilution was for $C$. mucunoides $\left(2^{-10}\right)$. Viral templates in undiluted extracts of both $L$. esculentum and $C$. mucunoides were detected with the optimized IC-PCR protocol. IC-PCR detected viral templates at greater dilutions of extracts of all plant species under investigation ( $L$. esculentum at a dilution of $2^{-10}$, Sida spp. at $2^{-10}$, and $R$. minima and C. mucunoides at $2^{-15}$ ) than Std-PCR (L. esculentum and $R$. minima at $2^{-8}$, Sida spp. at $2^{-9}$, and $C$. mucunoides at $2^{-10}$ ) and DB-PCR (L. esculentum at $2^{-8}$ and Sida spp. at $2^{-5} ; R$. minima and $C$. mucunoides were not tested). Apart from differ- ences in minimum and maximum detectable limits, which varied in a species-specific manner and according to the assay used for detection, the amplified band intensity also varied among the three assay techniques. IC-PCR consistently resulted in amplified band intensity superior to that obtained with the other two assays, irrespective of the plant species.

\section{DISCUSSION}

The use of clarified plant extracts in detecting viral DNA through PCR amplification provides several advantages. It elimi-

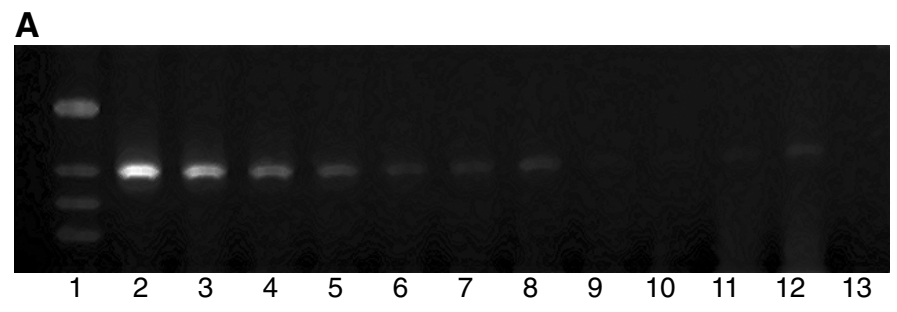

B

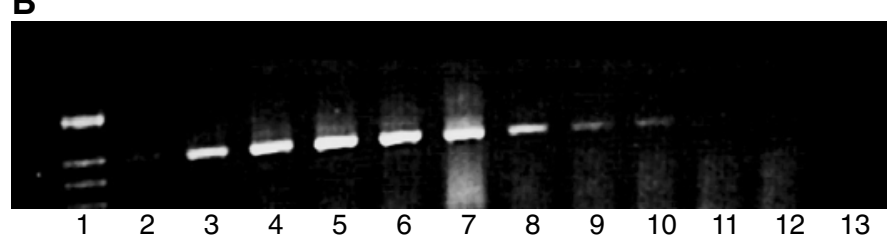

C

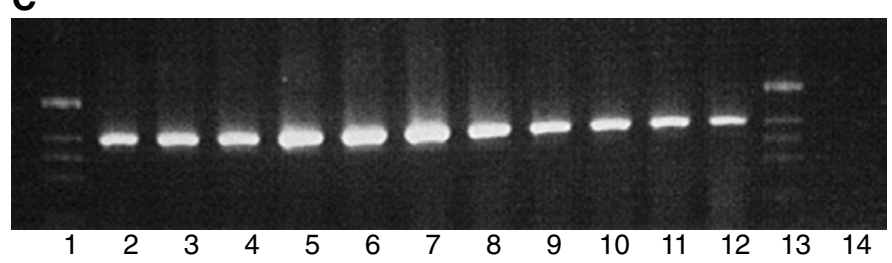

Fig. 1. Comparison of three methods for detection of begomoviruses by polymerase chain reaction (PCR). A, Direct-binding PCR. Lane 1: 1-kb DNA ladder; lanes 2 to 12: extract of infected tomato leaves diluted to $2^{0}$ to $2^{-10}$ in buffer C (20 mM Tris- $\mathrm{HCl}$, pH 8.0; $138 \mathrm{mM} \mathrm{NaCl} ; 1 \mathrm{mM}$ polyvinylpyrrolidone; $0.05 \%$ Tween $20 ; 3 \mathrm{mM} \mathrm{KCl}$; and $3 \mathrm{mM} \mathrm{NaN}_{3}$ per liter, $\mathrm{pH}$ 7.4); lane 13: extract of healthy tomato leaves diluted to $2^{-5}$ in buffer C. B, Standard PCR. Lane 1: 1-kb DNA ladder; lanes 2 to 12: extract of infected tomato leaves diluted to $2^{0}$ to $2^{-10}$ in buffer $\mathrm{C}$; lane 13: extract of healthy tomato leaves diluted to $2^{-5}$ in buffer C. C, Immunocapture PCR. Lane 1: 1-kb DNA ladder; lanes 2 to 12: extract of infected tomato leaves diluted to $2^{0}$ to $2^{-10}$ in buffer $\mathrm{C}$; lane 13: 1-kb DNA ladder; lane 14: extract of healthy tomato leaves diluted to $2^{-5}$ in buffer C. Amplified DNA fragments are approximately $400 \mathrm{bp}$.


merase chain reaction (PCR) assays of tomato extract diluted $2^{0}$ to $2^{-10}$ in buffer $C^{a, b}$

\begin{tabular}{|c|c|c|c|c|c|c|c|c|c|c|c|c|}
\hline & \multicolumn{11}{|c|}{ Dilution } & \multirow[b]{2}{*}{$\mathrm{NC}^{\mathrm{c}}$} \\
\hline & $2^{0}$ & $2^{-1}$ & $2^{-2}$ & $2^{-3}$ & $2^{-4}$ & $2^{-5}$ & $2^{-6}$ & $2^{-7}$ & $2^{-8}$ & $2^{-9}$ & $2^{-10}$ & \\
\hline \multicolumn{13}{|l|}{ Standard PCR } \\
\hline Replicate 1 & + & ++ & +++ & +++ & +++ & ++++ & ++++ & ++ & ++ & - & - & - \\
\hline Replicate 2 & + & ++ & +++ & +++ & +++ & ++++ & ++++ & ++ & ++ & - & - & - \\
\hline \multicolumn{13}{|c|}{ Direct-binding $\mathrm{PCR}^{\mathrm{d}}$} \\
\hline Replicate 1 & + & + & + & - & - & - & - & - & - & - & - & - \\
\hline Replicate 2 & - & - & + & ++ & ++ & + & - & - & - & - & - & - \\
\hline \multicolumn{13}{|c|}{ Immunocapture $\mathrm{PCR}^{\mathrm{d}, \mathrm{e}}$} \\
\hline Replicate 1 & +++ & ++++ & ++++ & ++++ & ++++ & ++++ & ++++ & ++++ & ++++ & ++++ & +++ & - \\
\hline Replicate 2 & +++ & ++++ & ++++ & ++++ & ++++ & ++++ & ++++ & ++++ & ++++ & ++++ & +++ & - \\
\hline
\end{tabular}

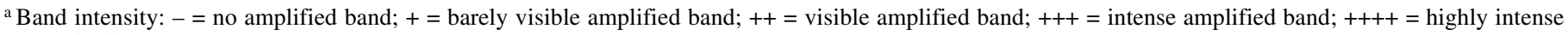
amplified band.

${ }^{\mathrm{b}}$ Buffer $\mathrm{C}$ contained $20 \mathrm{mM}$ Tris- $\mathrm{HCl}(\mathrm{pH} 8.0), 138 \mathrm{mM} \mathrm{NaCl}, 1 \mathrm{mM}$ polyvinylpyrrolidone, $0.05 \%$ Tween $20,3 \mathrm{mM} \mathrm{KCl}$, and 3 mM NaN 3 per liter (pH 7.4).

${ }^{\mathrm{c}}$ Negative controls: extracts of healthy tomato leaves were prepared, diluted to $2^{-5}$ in buffer $\mathrm{C}$, and amplified.

${ }^{\mathrm{d}}$ Diluted extracts were incubated at $4^{\circ} \mathrm{C}$ for $16 \mathrm{~h}$.

e Antibody concentration of 1:500. 
nates the time-consuming steps of total nucleic acid isolation and purification, avoids possible inhibitory effects of co-isolated impurities on PCR amplification, and allows detection of viruses that occur in low titers (32). Std-PCR using clarified plant extracts is the least time-consuming, but it may be affected by inhibitory substances in the extracts.

We first optimized the PCR amplification in order to maximize sensitivity and reproducibility of detection of virus templates in crude extracts using degenerate primers $(8,30)$. Annealing temperature, type and concentration of PCR additives, and $\mathrm{MgCl}_{2}$ concentration were first adjusted to improve sensitivity and reproducibility. Sensitivity was assessed by the detection limits (detection of the initial and end points of dilution) and the intensity of amplified bands.

The type of buffer and capture conditions were varied to improve the sensitivity and reliability of detection by IC-PCR and DB-PCR. Extraction buffer $C$ provided the greatest sensitivity and reproducibility. The extraction buffer may affect the stability of the viral particle, which usually exists over a narrow $\mathrm{pH}$ range $(12,13)$. In instances in which immunoaffinity is the basis of detection, capsid integrity becomes especially important (13). The components of a successful buffer may also assist in releasing the virus from cell constituents, while protecting it from endogenous nucleases (29) and polyphenoloxidases present in plant extracts (7). Buffer components may also act as competitors to exclude inhibitors, such as tannins, in the extraction medium (12).

The efficacy of the optimized detection system was determined by subjecting serial dilutions of crude extracts of geminivirusinfected plants of different species to the optimized PCR-based protocol. IC-PCR had the lowest detection limits for all species and was superior to Std-PCR by one to seven orders of dilution. Depending on the species and the tissue specificity of certain begomoviruses (e.g., phloem limitations), detection may reflect the variation in the begomovirus titer in different species. This study indicates that IC-PCR may be the most sensitive tool for the detection of begomoviruses, and it may be particularly useful for those that are present in low or variable titers and for plant species that contain various levels of PCR inhibitors.

The efficiency of IC-PCR may be explained by its ability to concentrate the viral template in the extract by the selective affinity of the epitope-antibody complex during the capture phase. Wetzel et al. (32) and Rowhani et al. (26) found IC-PCR to be effective with low-titer viruses, such as Plum pox virus, and viruses of some woody plants. This efficiency may also stem from an ability to selectively eliminate PCR inhibitors during washing.
However, detection with IC-PCR was not achieved with undiluted plant extracts, with the exception of tomato and $C$. mucunoides (and with Std-PCR using tomato extracts only). These results may show that while excess PCR inhibitors may be eliminated during the washing step of the IC-PCR process, such compounds may hinder the capture phase of IC-PCR. For instance, it is plausible that the high mucilage content of extracts of Sida spp. may retard the interaction between antibody and antigen during the capture phase. Detection is then achieved only as the level of inhibitors is reduced (by dilution), so that a sufficient amount of antigen can be captured and subsequently amplified. Further dilution of extracts decreases the level of inhibitors, but it also decreases the concentration of the viral template. Std-PCR is more sensitive to these effects than IC-PCR (i.e., $1 \mu$ of extract is added to the PCR mix for Std-PCR, compared with $50 \mu \mathrm{l}$ of extract incubated for ICPCR) in its detection limits and amplified band intensity, as confirmed by the results of this study.

DB-PCR gave inconsistent results for amplified band intensity and detection limits in extracts of infected tomato. Optimizing this assay would be difficult, because the precise mechanism by which the viral DNA is adsorbed to or immobilized on the solid support of the microcentrifuge tube wall is not well understood $(26,33)$ and may vary according to the individual properties of each tube. Hence, it is understandable that we were unable to obtain consistent results with this method, despite varying the incubation conditions.

Diagnostic PCR should fulfill several qualitative characteristics, of which the most important are specificity, sensitivity, efficiency, and reproducibility $(8,10,15,17)$. Deng et al. (8) designed degenerate primers to flank the $5^{\prime}$ terminal region of the coat protein gene to specifically detect begomoviruses. Umaharan et al. (30) showed that amplification followed by sequencing of this region can be used to identify new begomoviruses. Here we show that specificity, selectivity, efficiency, and reproducibility in detecting begomovirus infection can be achieved by an optimized IC-PCR protocol using degenerate primers flanking the $5^{\prime}$ terminus of the coat protein gene.

In summary, our results show that IC-PCR is the most efficient among the systems tested in detecting begomoviruses in different species. IC-PCR can be used for detecting and identifying begomoviruses in clarified plant extracts with degenerate primers, without prior isolation of total nucleic acids. This technique takes advantage of commercially available polyclonal geminivirus antisera and may lead to the development of sensitive and rapid singletube assays.

TABLE 2. Amplified band intensity obtained by standard, direct-binding, and immunocapture polymerase chain reaction (PCR) assays of diluted clarified leaf extracts of different plant species ${ }^{\mathrm{a}}$

\begin{tabular}{|c|c|c|c|c|c|c|c|c|c|c|c|c|c|c|c|c|c|}
\hline & \multicolumn{16}{|c|}{ Dilution } & \multirow[b]{2}{*}{$\mathrm{NC}^{\mathrm{b}}$} \\
\hline & $2^{0}$ & $2^{-1}$ & $2^{-2}$ & $2^{-3}$ & $2^{-4}$ & $2^{-5}$ & $2^{-6}$ & $2^{-7}$ & $2^{-8}$ & $2^{-9}$ & $2^{-10}$ & $2^{-11}$ & $2^{-12}$ & $2^{-13}$ & $2^{-14}$ & $2^{-15}$ & \\
\hline \multicolumn{18}{|l|}{ Sida spp. } \\
\hline Standard PCR & - & - & - & - & + & + & + & + & + & + & - & - & - & - & - & - & - \\
\hline Immunocapture PCR & - & - & ++ & + & + & ++ & +++ & +++ & ++ & ++ & ++ & - & - & - & - & - & - \\
\hline Direct-binding PCR & - & - & - & - & ++ & + & - & - & - & - & - & - & - & - & - & - & - \\
\hline \multicolumn{18}{|l|}{ Rhynchosia minima } \\
\hline Standard PCR & - & - & + & + & ++ & + & + & + & + & - & - & - & - & - & - & - & - \\
\hline Immunocapture PCR & - & - & + & ++ & +++ & ++++ & ++++ & ++++ & ++++ & +++ & +++ & ++ & ++ & ++ & ++ & ++ & - \\
\hline \multicolumn{18}{|l|}{$\begin{array}{l}\text { Calopogonium тиси- } \\
\text { noides }\end{array}$} \\
\hline Standard PCR & - & - & - & +++ & ++++ & ++++ & ++++ & ++++ & ++++ & ++++ & +++ & - & - & - & - & - & - \\
\hline Immunocapture PCR & ++++ & ++++ & ++++ & ++++ & ++++ & ++++ & ++++ & ++++ & ++++ & ++++ & ++++ & +++ & ++ & ++ & ++ & ++ & - \\
\hline \multicolumn{18}{|l|}{ Lycopersicon esculentum } \\
\hline Standard PCR & + & +++ & ++++ & ++++ & ++++ & ++++ & ++++ & + & + & - & - & - & - & - & - & - & - \\
\hline Immunocapture PCR & ++++ & ++++ & ++++ & ++++ & ++++ & ++++ & ++++ & ++++ & ++++ & ++++ & ++++ & - & - & - & - & - & - \\
\hline Direct-binding PCR & +++ & +++ & ++ & ++ & + & + & + & + & + & - & - & - & - & - & - & - & - \\
\hline
\end{tabular}

${ }^{a}$ Band intensity: $-=$ no amplified band; $+=$ barely visible amplified band; $++=$ visible amplified band; $+++=$ intense amplified band; $++++=$ highly intense amplified band.

${ }^{\mathrm{b}}$ Negative controls: extracts of healthy tomato leaves were prepared, diluted to $2^{-5}$ in buffer $\mathrm{C}(20 \mathrm{mM}$ Tris- $\mathrm{HCl}, \mathrm{pH} 8.0 ; 138 \mathrm{mM} \mathrm{NaCl} ; 1 \mathrm{mM}$ polyvinylpyrrolidone; $0.05 \%$ Tween $20 ; 3 \mathrm{mM} \mathrm{KCl}$; and $3 \mathrm{mM} \mathrm{NaN}_{3}$ per liter, $\mathrm{pH} 7.4$ ), and amplified. 


\section{LITERATURE CITED}

1. Brown, J. K., and Bird, J. 1992. Whitefly-transmitted geminiviruses and associated disorders in the Americas and the Caribbean Basin. Plant Dis. 76:220-225.

2. Brown, J. K., and Nelson, M. R. 1988. Transmission, host range, and virus-vector relationships of chino del tomate virus, a whiteflytransmitted geminivirus from Sinaloa, Mexico. Plant Dis. 72:866-869.

3. Cambra, M., Olmos, A., Asensio, M., Esteban, O., Gorris, M. T., Boscia, D., and Candresse, T. 1998. Detection and typing of Prunus viruses in plant tissues and in vectors by print and spot-capture PCR, heminestedPCR and PCR-ELISA. Acta Hortic. 472:257-264.

4. Candresse, T., Lanneau, M., Revers, F., Macquaire, G., German, S., Dunez, J., Grasseau, N., and Malinovsky, T. 1995. An immunocapture PCR assay adapted to the detection and the analysis of the molecular variability of apple chlorotic leaf spot virus. Acta. Hortic. 386:136-147.

5. Cook, G., Rybicki, E. P., and Pietersen, G. 1998. Characterisation of a new potyvirus isolated from peanut (Arachis hypogaea). Plant Pathol. 47:348-354.

6. Coutts, R. H. A., Coffin, R. S., Roberts, E. J. F., and Hamilton, W. D. O. 1991. The nucleotide sequence of the infectious cloned DNA components of potato yellow mosaic virus. J. Gen. Virol. 72:1515-1520.

7. Demeke, T., and Adams, R. P. 1992. The effects of plant polysaccharide and buffer additives on PCR. BioTechniques 12:332-334.

8. Deng, D., McGrath, P. F., Robinson, D. J., and Harrison, B. D. 1994. Detection and differentiation of whitefly-transmitted geminiviruses in plants and vector insects by the polymerase chain reaction with degenerate primers. Ann. Appl. Biol. 125:327-336.

9. Guzman, P., Arredondo, C. R., Emmatty, D., Portillo, R. J., and Gilbertson, R. L. 1997. Partial characterization of two whitefly-transmitted geminiviruses infecting tomatoes in Venezuela. Plant Dis. 81:312.

10. Harper, G., Dahal, G., Thottappilly, G., and Hull, R. 1999. Detection of episomal banana streak badnavirus by IC-PCR. J. Virol. Methods $79: 1-8$.

11. Hong, Y. G., and Harrison, B. D. 1995. Nucleotide sequences from tomato leaf curl viruses from different countries: Evidence for three geographically separate branches in evolution of the coat protein of whiteflytransmitted geminiviruses. J. Gen. Virol. 76:2043-2049.

12. Hill, S. 1984. Methods in Plant Virology. Vol. 1. Blackwell Scientific Publications, Oxford.

13. Hull, R. 2002. Matthews' Plant Virology. 4th ed. Academic Press, London.

14. James, D. 1998. Factors affecting the detection of apple stem grooving virus by PCR analysis. Acta Hortic. 472:119-124.

15. Jansen, R. W., Siegl, G., and Lemon, S. M. 1990. Molecular epidemiology of human hepatitis A virus defined by an antigen-capture polymerase chain reaction method. Proc. Natl. Acad. Sci. USA 87:28672871 .

16. McGlashan, D., Polston, J. E., and Bois, D. 1994. Tomato yellow leaf curl geminivirus in Jamaica. Plant Dis. 78:1219.

17. McPherson, M. J., Quirke, P., and Taylor, G. R. 1991. PCR: A Practical Approach. IRL Press, New York.
18. Padidam, M., Beachy, R. N., and Fauquet, C. M. 1995. Classification and identification of geminiviruses using sequence comparisons. J. Gen. Virol. 76:249-263.

19. Polston, J. E., and Anderson, P. K. 1997. The emergence of whiteflytransmitted geminiviruses in tomato in the Western Hemisphere. Plant Dis. 81:1358-1369.

20. Polston, J. E., Bois, D., Ano, G., Poliakoff, F., and Urbino, C. 1998. Occurrence of a strain of potato yellow mosaic geminivirus infecting tomato in the eastern Caribbean. Plant Dis. 82:126.

21. Polston, J. E., Hiebert, E., McGovern, R. J., Stansly, P. A., and Schuster, D. J. 1993. Host range of tomato mottle virus, a new geminivirus infecting tomato in Florida. Plant Dis. 77:1181-1184.

22. Rabenstein, F., and Schubert, J. 1997. Detection of ryegrass mosaic virus by monoclonal antibodies and immunocapture PCR. Page 97 in: Diagnosis and Identification of Plant Pathogens. Proc. 4th Int. Symp. Eur. Found. Plant Pathol. Kluwer Academic, Dordrecht, Netherlands.

23. Ramos, P. L., Guerra, O., Peral, R., Oramas, P., Guevara, R. G., and Rivera-Bustamante, R. 1997. Taino tomato mottle virus, a new bipartite geminivirus from Cuba. Plant Dis. 81:1095.

24. Roberts, E. J. F., Buck, K. W., and Coutts, R. H. A. 1988. Characterisation of potato yellow mosaic virus as a geminivirus with a bipartite genome. Intervirology 29:162-169.

25. Rojas, M. R., Gilbertson, R. L., Russell, D. R., and Maxwell, D. P. 1993. Use of degenerate primers in the polymerase chain reaction to detect whitefly-transmitted geminiviruses. Plant Dis. 77:340-347.

26. Rowhani, A., Maningas, M. A., Lile, L. S., Daubert, S. D., and Golino, D. A. 1995. Development of a detection system for viruses of woody plants based on PCR analysis of immobilized virions. Phytopathology 85:347-352.

27. Roye, M. E., McLaughlin, W. A., Nakhla, M. K., and Maxwell, D. P. 1997. Genetic diversity among geminiviruses associated with the weed species Sida spp., Macroptilium lathyroides, and Wissadula amplissima from Jamaica. Plant Dis. 81:1251-1258.

28. Rybicki, E. P., and Hughes, F. L. 1990. Detection and typing of maize streak virus and other distantly related geminiviruses of grasses by polymerase chain reaction amplification of a conserved viral sequence. $\mathrm{J}$. Gen. Virol. 71:2519-2526.

29. Scott, R. O., and Bendich, A. J. Plant Molecular Biology Manual. A6:110. Kluwer Academic, Dordrecht, Netherlands.

30. Umaharan, P., Padidam, M., Phelps, R. H., Beachy, R. N., and Fauquet, C. M. 1998. Distribution and diversity of geminiviruses in Trinidad and Tobago. Phytopathology 88:1262-1268.

31. Varveri, C., and Boutsika, K. 1998. Application of the immunocapturePCR technique for plum pox potyvirus detection under field conditions in Greece and assays to simplify standard techniques. Acta Hortic. 472:475-482.

32. Wetzel, J., Candresse, T., Macquaire, G., Ravelonandro, M., and Dunez, J. 1992. A highly sensitive immunocapture polymerase chain reaction method for plum pox potyvirus detection. J. Virol. Methods 39:27-37.

33. Wyatt, S. D., and Brown, J. K. 1996. Detection of subgroup III geminireaction. Phytopathology 86:1288-1293. 